\title{
Development of haploid embryos and plants of Lactuca sativa induced by distant pollination with Helianthus annuus and $H$. tuberosus
}

\author{
L. Piosik $\cdot$ E. Zenkteler $\cdot$ M. Zenkteler
}

Received: 10 June 2015/ Accepted: 9 October 2015/Published online: 17 October 2015

(C) The Author(s) 2015. This article is published with open access at Springerlink.com

\begin{abstract}
Haploidisation is a biotechnological method used to obtain plants with improved traits that are of use to humans. Lettuce (Lactuca sativa L.), a well-known and popular leafy vegetable, is consumed worldwide. Its haploid form would provide a good basis for producing a pure line of plants (doubled haploids) allowing new varieties to be regenerated. The main aim of this work was to develop an effective haploidisation method for this economically important species. In order to stimulate the development of haploid embryos of lettuce based on our previous experience, we conducted in vivo distant pollination with fresh pollen grains of Helianthus annuus L. or $H$. tuberosus L. Because the haploid proembryos obtained after pollination did not develop further (despite the presence of cellular endosperm), we implemented the technique of in vitro culture of an isolated embryo sacs (surrounded by endothelium) with parthenogenetic embryos on various, modified Murashige and Skoog media. During the in vitro culture, we observed the formation of callus tissue and, after subsequent cultures of calluses, 23 haploid L. sativa plants were regenerated. The haploid status of the regenerated plantlets was confirmed by
\end{abstract}

Ł. Piosik $(\bowtie) \cdot$ E. Zenkteler · M. Zenkteler Department of General Botany, Faculty of Biology, Institute of Experimental Biology, Umultowska 89, 61-614 Poznan, Poland e-mail: 1.piosik@amu.edu.pl estimation of the genome size by flow cytometry, chromosome counting in root tips, stomata cell size and by disturbances in pollen formation resulting from abnormal microsporogenesis. This paper contains the complete protocol for obtaining haploid plants of $L$. sativa.

Keywords Haploid - Lettuce · Parthenogenesis · Callus proliferation $\cdot$ Distant pollination $\cdot$ In vitro culture

\section{Introduction}

Haploid plants (characterized by gametic number of chromosomes) are both significant and necessary elements in plant improvement programs. They are important in many basic research disciplines, such as biotechnology, genetics, crop evolution and plant breeding. Moreover, haploids are very useful as a base for the production of homozygous plants in that they expedite the breeding process and can lead to an increase in crop yield.

Lactuca sativa L. (lettuce) is a very popular and economically significant leafy vegetable that belongs to the Asteraceae family (De Vries 1997). Lettuce leaves are highly nutritious and used widely as a garnish for a variety of dishes. This species has relatively low requirements with regard to cultivation conditions (Bradley et al. 2009). An efficient 
haploidisation method would have great potential for improving many phenotypic characteristics of this species.

Modern biotechnology offers many recognised and effective techniques for inducing the development of haploid plants. The most common methods are:

1. Self-pollination using inactivated pollen grains: for example, a method of deactivating pollen grains by gamma- or X-rays was used to induce the development of haploid embryos of Cucurbita moschata Duchesne ex. Poir (Kurtar et al. 2009), Cucumis melo (Nasertorabi et al. 2012) and Actinidia deliciosa (Musiał and Przywara 1998, 1999; Pandey et al. 1990).

2. Distant pollination of species which belong to different species or genera: for example, haploid embryos of Cichorium intybus L. were obtained a few days after pollination with Cicerbita alpina Walbr. (Dore et al. 1996) and also in carrot after crossing with parsley with the simultaneous application of 2,4-dichlorophenoxyacetic acid (2,4-D) (Kiełkowska et al. 2014).

3. The bulbosum method-using in order to induce the elimination of paternal chromosomes of embryo cells has been applied to several species, such as Hordeum vulgare L., after crossing with $H$. bulbosum L. A process of elimination of bulbous barley chromosomes was observed in hybrid embryos (Kasha and Kao 1970). Haploid embryos were also obtained after crossing wheat and maize (Gu et al. 2008).

4. Androgenesis this is a method for obtaining haploids from in vitro cultures of anthers and isolated microspores; it has been used successfully in many species, such as Brassica napus (Cegielska-Taras 2004; Dubas et al. 2014), Lycopersicon esculentum Mill. (Shtereva et al. 1998), Aesculus hippocastanum L. (Radojevic et al. 2000), Triticum aestivum L. (Kyung-Moon and Baenziger 2005) and in Solanaceae crops (Segui-Smiarro et al. 2011).

5. Gynogenesis this method allows haploids to be obtained from an unfertilised egg cell or synergids (Mól 1999; Musiał et al. 2005) through the culturing of unfertilised ovules or ovaries, such as in Beta vulgaris L. (Gośka et al. 2004), Gentiana triflora Pall. (Doi et al. 2011) or Allium cepa (Musiał et al. 2001).
Because a protocol for the haploidisation of L. sativa has not yet been developed, the main aim of the work reported here was to find an effective method for obtaining haploid plants of this species. The first report on the development of haploid, globular embryos of $L$. sativa after distant pollination and after chemical treatment was published by Piosik (2013). Haploid embryos of lettuce were induced by distant pollination with pollen grains of 18 of 25 species (belonging mainly to genera of the family Asteraceae) and by the application of seven tested chemicals to stigmas of $L$. sativa (Piosik 2013). The frequency of developed parthenogenetic embryos was dependent on the pollinator species, with the most effective being Helianthus annuus (19\%) and H. tuberosus (16\%), or on the type of chemical inductor, with the most efficient being dicamba (15\%) and picloram (14\%) (Piosik 2013). Unfortunately, none of the parthenogenetic embryos that were produced developed further and they degenerated in vivo very quickly. To induce the growth of haploid embryos and lettuce plants, we produced cultures of ovaries, ovules and embryo sacs (surrounded by endothelium) in vitro upon their isolation after crosspollination and chemical treatment. We observed that callus tissue was produced from the haploid embryo (developed after the pollination of L. sativa $\times H$. annuus) inside one of the embryo sacs cultured in vitro. This result was very promising because the callus originated from the dividing cells of the haploid proembryo. Consequently, we focused our experiments on enabling the development of embryos after pollination with $H$. annuus or $H$. tuberosus and on in vitro cultures of these proembryos inside whole embryo sacs. Finally, we developed an efficient method of producing haploid L. sativa plants from haploid calluses that proliferated from parthenogenetic embryos produced after cross-pollination with Helianthus pollen grains.

\section{Materials and methods}

Plant material

The experimental material comprised male-sterile (Fig. 1a-d) and fertile (Fig. 1e, control) forms of Lactuca sativa (obtained from Rijk Zwaan R\&D, Fijnaart, The Netherlands). Fertile plants of $H$. annuи and $H$. tuberosus (growing wild) were used as pollen donors. Male-sterile plants of lettuce were grown in a 

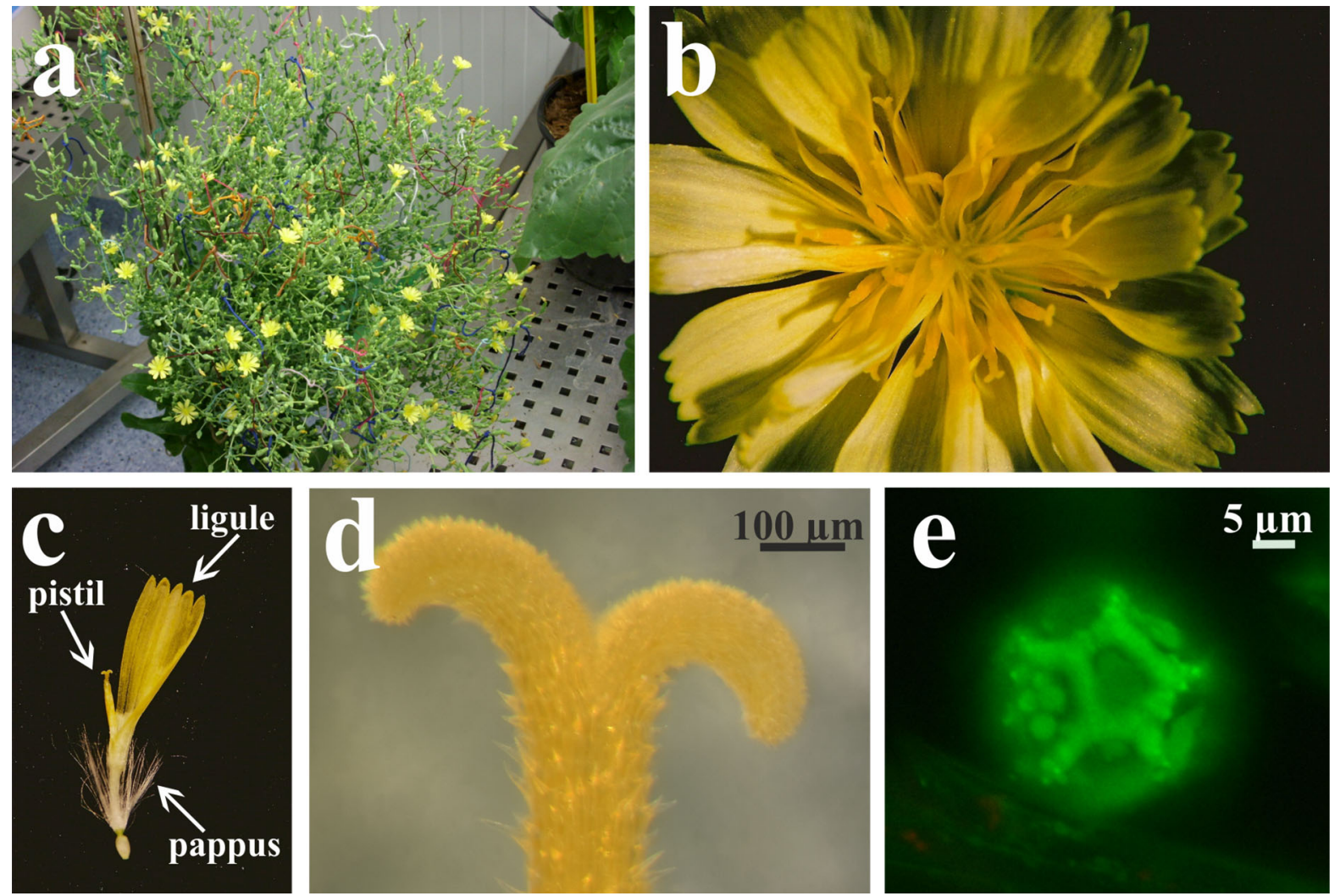

Fig. 1 Flowers and pollen used in cross-pollination: a male-sterile lettuce plant with numerous flowering inflorescences; $\mathbf{b}$ flower head of lettuce composed of florets (c); $\mathbf{d}$ receptive stigma of $L$. sativa; $\mathbf{e}$ isolated pollen grain of $L$. sativa (control)

culture room, using a 16/8-h photoperiod, photosynthetic photon flux density of $250-300 \mu \mathrm{mol} \mathrm{m} \mathrm{m}^{-2} \mathrm{~s}^{-1}$, humidity of $40 \%$ and appropriate irrigation. Fertile forms of lettuce were cultured in a separate culture room.

\section{Crossing technique}

For cross-pollination in vivo, pistils of open inflorescences of lettuce were used (Fig. 1a-c). Receptive stigmas of L. sativa (Fig. 1d) were hand-pollinated with freshly collected pollen grains of $H$. annuus and H. tuberosus (Table 1) using a tiny brush. All pollinated inflorescences were labelled using coloured threads.

\section{Analysis of cross-pollination}

The germination of foreign pollen grains on stigmas of L. sativa was analysed under a fluorescence microscope with aniline blue $\left(1 \mathrm{~g} / 100 \mathrm{ml}\right.$ of $\mathrm{H}_{2} \mathrm{O}$, $\mathrm{pH}=7.2) 1$ day after pollination (1 DAP). For analysis of the development of haploid embryos, ovaries and ovules were isolated $6 \mathrm{~h}$ after pollination (HAP) until 6 DAP, fixed in FAA solution $(90 \mathrm{ml}$ of $70 \%$ ethanol $+5 \mathrm{ml}$ of formalin $+5 \mathrm{ml}$ of glacial acetic acid) embedded in Paraplast, sectioned with a microtome (Reichert; section thickness: $12 \mu \mathrm{m}$ ), stained with iron haematoxylin $(3 \mathrm{~g} / 500 \mathrm{ml}$ of $80 \%$ ethanol) and counterstained with fast green FCF (0.3 g/100 ml of clove oil). Stained permanent slides were enclosed in Entellan (Merck). Chromosome number was established on mitotic metaphase plates of embryos on squashed slides of ovules or isolated embryo sacs (surrounded by endothelium) stained with acetocarmine (1\% solution of carmine in $45 \%$ glacial acetic acid). The ratio of the number of haploid proembryos produced after crossing to the total number of analysed ovules is expressed as a percentage. 
Table 1 Frequency of haploid embryos after distant pollination with Helianthus pollen

\begin{tabular}{llll}
\hline Pollen donor species & $\begin{array}{l}\text { Number of pollinated } \\
\text { inflorescences }\end{array}$ & $\begin{array}{l}\text { Germination of pollen grains } \\
\text { on L. sativa stigma }\end{array}$ & $\begin{array}{l}\text { Frequency of haploid } \\
\text { embryos (\%) }\end{array}$ \\
\hline Helianthus annuus & 6600 & + & 15 \\
Helianthus tuberosus & 7200 & + & 16 \\
\hline
\end{tabular}

Embryo-rescue technique and plant regeneration

Enlarged ovaries obtained at 5-10 DAP were harvested and their surfaces were disinfected by 3-min treatment with $2 \%$ active chlorine water with consecutive rinses in sterile $\mathrm{H}_{2} \mathrm{O}$. Ovaries were dissected under sterile conditions and the embryo sacs (surrounded by endothelium) with visible globular embryos were isolated. Embryo sacs were plated in Petri dishes (50 mm diameter) containing one of 28 combinations of Murashige and Skoog (MS) media of various compositions (Murashige and Skoog 1962; Table 2). Plates with cultured embryo sacs were kept in the dark at room temperature $\left(22^{\circ} \mathrm{C}\right)$ for 1 week and then transferred to the light $\left(250 \mu \mathrm{mol} \mathrm{m}{ }^{-2} \mathrm{~s}^{-1}\right)$ at $16{ }^{\circ} \mathrm{C}$. The growth of the globular embryos was analysed in in vitro cultures.

Calluses developed from the globular embryos on only two media: MS + BAP $2 \mathrm{mg} \mathrm{l}^{-1}+$ IAA $1 \mathrm{mg} \mathrm{l}^{-1}$, and $\mathrm{MS}+\mathrm{NAA} 1 \mathrm{mg} \mathrm{l}^{-1}+2,4-\mathrm{D}$ $1 \mathrm{mg} \mathrm{l}^{-1}$ (Table 3). After 3-4 weeks of culturing, calluses were placed in jars with a regeneration MS medium modified by the addition of $2 \mathrm{mg} \mathrm{l}^{-1}$ kinetin for 4 weeks. Well-developed rooting plantlets were formed and moved to water containing mineral salts. 7 days later, plantlets were transferred to pots containing universal gardening soil (Kronen). Plants were grown in a culture room with a $16 / 8$-h photoperiod, temperature $22{ }^{\circ} \mathrm{C}$ day $/ 16{ }^{\circ} \mathrm{C}$ night, photosynthetic photon flux density of $250-300 \mu \mathrm{mol} \mathrm{m} \mathrm{m}^{-2} \mathrm{~s}^{-1}$ and humidity of $40 \%$.

Estimation of the ploidy of regenerated plants

\section{Flow cytometry}

All obtained plants were examined by flow cytometry using small pieces of tissue $\left(1 \mathrm{~cm}^{2}\right)$ harvested from young leaves. Samples were prepared according to Galbraith et al. (1983). Plant tissue was chopped with a razor blade in Galbraith buffer with the addition of
$2 \%$ PVP-10 (polyvinylpyrrolidone) and $15 \mathrm{nM} \beta$ mercaptoethanol and stained with propidium iodide. For analysis of the ploidy level, diploid $L$. sativa was used as an external standard. The suspensions were passed through a nylon filter with a $50-\mu \mathrm{m}$ mesh size. For each leaf sample, around 6000 nuclei were analysed using a logarithmic scale on a Partec flow cytometer. Histograms were analysed using DPAC software (Partec, Germany).

\section{Chromosome number counting}

Young roots of regenerated haploid plants and also roots of diploid plants were pretreated with a solution of $0.1 \%$ colchicine in water at $22{ }^{\circ} \mathrm{C}(1 \mathrm{~h})$, then fixed in FAA $(90 \mathrm{ml}$ of $70 \%$ ethanol $+5 \mathrm{ml}$ of formalin $+5 \mathrm{ml}$ of glacial acetic acid; $1 \mathrm{~h}$ ), stained with acetocarmine ( $1 \%$ solution of carmine in $45 \%$ glacial acetic acid; $20 \mathrm{~min}$ ) and macerated in $1 \mathrm{M}$ hydrochloric acid. The number of chromosomes was established in meristematic cells at the metaphase on squashed slides under a light microscope.

\section{Length of leaf stomata}

Analysis of the length of stomata was performed on the adaxial epidermis of leaves of haploid and diploid plants (control). Small pieces of leaves $\left(0.5 \mathrm{~mm}^{2}\right)$ were excised. The epidermis was removed from leaves by using a small scalpel and then placed in a drop of distilled water. Measurements were performed under a light microscope (Axioscope A.1, Zeiss) using AxioVision 8.1 software. For each leaf sample, ten stomata were analysed in six replications. Statistical analyses were performed by Student's $t$ test using Statistica 10 software (Tulsa, USA).

\section{Analysis of late stages of microsporogenesis}

Anthers isolated 3 and 9 days before anthesis and on the day of flowering were fixed in FAA, 
Table 2 MS modified media used for in vitro cultures of haploid embryos

\begin{tabular}{|c|c|}
\hline Medium & Number of obtained calluses \\
\hline MS & - \\
\hline $\mathrm{MS}+\mathrm{KIN} 1 \mathrm{mg}^{-1}$ & - \\
\hline $\mathrm{MS}+\mathrm{KIN} 1 \mathrm{mg} \mathrm{l}^{-1}+\mathrm{BAP} 1 \mathrm{mg} 1^{-1}$ & - \\
\hline $\mathrm{MS}+\mathrm{KIN} 2 \mathrm{mg} \mathrm{1}^{-1}$ & - \\
\hline $\mathrm{MS}+\mathrm{KIN} 2 \mathrm{mg}^{-1}+\mathrm{IAA} 1 \mathrm{mg} 1^{-1}+$ casein hydrolysate $200 \mathrm{mg} 1^{-1}$ & - \\
\hline $\mathrm{MS}+\mathrm{BAP} 2 \mathrm{mg}^{-1}$ & - \\
\hline $\mathrm{MS}+\mathrm{BAP} 2 \mathrm{mg}^{-1}+\mathrm{IAA} 1 \mathrm{mg} 1^{-1}$ & 15 \\
\hline MS + ZEA $1 \mathrm{mg}^{-1}+$ casein hydrolysate $250 \mathrm{mg} \mathrm{l}^{-1}+$ sucrose $6 \%$ & - \\
\hline $\mathrm{MS}+\mathrm{IAA} 1 \mathrm{mg}^{-1}$ & - \\
\hline $\mathrm{MS}+\mathrm{IAA} 1 \mathrm{mg}^{-1}+\mathrm{BAP} 0,5 \mathrm{mg}^{-1}$ & - \\
\hline $\mathrm{MS}+\mathrm{IAA} 1 \mathrm{mg} \mathrm{l}^{-1}+$ coconut water $40 \mathrm{ml} 1^{-1}+$ sucrose $6 \%$ & - \\
\hline $\mathrm{MS}+\mathrm{IAA} 2 \mathrm{mg}^{-1}+$ sucrose $5 \%$ & - \\
\hline $\mathrm{MS}+\mathrm{IAA} 2 \mathrm{mg} \mathrm{l}^{-1}+\mathrm{BAP} 0,2 \mathrm{mg} \cdot \mathrm{1}^{-1}$ & - \\
\hline $\mathrm{MS}+\mathrm{NAA} 1 \mathrm{mg} \mathrm{l}^{-1}$ & - \\
\hline $\mathrm{MS}+\mathrm{NAA} 1 \mathrm{mg} \mathrm{l}^{-1}+2,4-\mathrm{D} 1 \mathrm{mg} \mathrm{l}^{-1}$ & 14 \\
\hline MS + NAA $1 \mathrm{mg} \mathrm{l}^{-1}+$ coconut water $40 \mathrm{ml} \mathrm{l}^{-1}+$ casein hydrolysate $250 \mathrm{mg}^{-1}+$ sucrose $5 \%$ & - \\
\hline $\mathrm{MS}+\mathrm{NAA} 2 \mathrm{mg}^{-1}+\mathrm{BAP} 2 \mathrm{mg} \mathrm{l}^{-1}$ & - \\
\hline $\mathrm{MS}+2,4 \mathrm{D} 1 \mathrm{mg} \mathrm{l}^{-1}+$ sucrose $5 \%$ & - \\
\hline 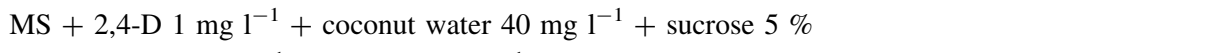 & - \\
\hline $\mathrm{MS}+\mathrm{DIC} 0,5 \mathrm{mg}^{-1}+\mathrm{BAP} 0,3 \mathrm{mg}^{-1}$ & - \\
\hline $\mathrm{MS}+\mathrm{DIC} 1 \mathrm{mg}^{-1}+\mathrm{BAP} 0,5 \mathrm{mg} 1^{-1}$ & - \\
\hline MS + sucrose $6 \%$ & - \\
\hline $\mathrm{MS}+$ colchicine $50 \mathrm{mg}^{-1}$ & - \\
\hline $\mathrm{MS}+$ glutamine $16 \mathrm{mg} \mathrm{l}^{-1}$ & - \\
\hline $\mathrm{MS}+$ coconut water $40 \mathrm{mg} \mathrm{l}^{-1}+$ sucrose $10 \%$ & - \\
\hline $\mathrm{MS}+$ coconut water $40 \mathrm{mg}^{-1}+$ sucrose $15 \%$ & - \\
\hline MS + casein hydrolysate $100 \mathrm{mg}^{-1}+$ sucrose $10 \%$ & - \\
\hline MS + casein hydrolysate $250 \mathrm{mg}^{-1}+$ sucrose $10 \%$ & - \\
\hline
\end{tabular}

Table 3 Efficiency of induction of callus development via cultures of embryo sacs with haploid embryos in vitro

\begin{tabular}{|c|c|c|c|c|}
\hline Medium & Cross combination & $\begin{array}{l}\text { Number of } \\
\text { cultured } \\
\text { embryo sacs }\end{array}$ & $\begin{array}{l}\text { Number of } \\
\text { obtained } \\
\text { calluses }\end{array}$ & $\begin{array}{l}\text { Number of } \\
\text { regenerated } \\
\text { plants }\end{array}$ \\
\hline \multirow[t]{2}{*}{$\mathrm{MS}+\mathrm{BAP} 2 \mathrm{mg}^{-1}+\mathrm{IAA} 1 \mathrm{mg}^{-1}$} & L. sativa $\times H$. annuus & 65 & 4 & 3 \\
\hline & L. sativa $\times H$. tuberosus & 72 & 10 & 8 \\
\hline \multirow[t]{2}{*}{$\mathrm{MS}+\mathrm{NAA} 1 \mathrm{mg} \mathrm{l}^{-1}+2,4-\mathrm{D} 1 \mathrm{mg} \mathrm{l}^{-1}$} & L. sativa $\times H$. annuus & 68 & 6 & 4 \\
\hline & L. sativa $\times H$. tuberosus & 60 & 9 & 8 \\
\hline
\end{tabular}

embedded in Paraplast, sectioned using a microtome (Reichert; section thickness: $12 \mu \mathrm{m}$ ), stained with iron haematoxylin $(3 \mathrm{~g} / 500 \mathrm{ml}$ of $80 \%$ ethanol and counterstained with fast green FCF
$(0.3 \mathrm{~g} / 100 \mathrm{ml}$ of clove oil). Stained permanent slides were enclosed in Entellan (Merck). Embryological analyses were performed under a light microscope. 


\section{Results}

Haploid embryos formation after intergeneric crossing

Pollen grains of the two species $(H$. annuus and $H$. tuberosus) independently used as pollinators had already begun to germinate on stigmas of $L$. sativa $1 \mathrm{~h}$ after pollination (Fig. 2a). Approximately $2 \mathrm{~h}$ after pollination, numerous well-developed, long pollen tubes had penetrated the stigmas and the styles (Fig. 2b). Microscopic analysis of the pollinated pistils revealed that, 2-3 h later, pollen tubes of $H$. annuus and $H$. tuberosus were entering the micropyle region of the embryo sac (Fig. 2c). Remnants of the foreign pollen tubes at the micropyle region of the embryo sac were preserved even up to 2 DAP (Fig. 2d). Two sperm cells were sometimes visible near the egg cell and central cell of the embryo sac, but they frequently remained inside the unburst pollen tubes (Fig. 2c). We did not observe fertilisation of the egg cell as well as a central cell. However, after crosspollination with $H$. annuus or $H$. tuberosus, globular embryos at very early stages were observed as early as 2 DAP. In the dividing cells of developing proembryos, a haploid number of chromosomes $(n=9)$ was counted (Fig. 2e). All analysed proembryos obtained after their induction with pollen grains of either Helianthus species were haploid and originated from the dividing unfertilised egg cell. The efficiency of embryo development induced after the pollination of $L$. sativa with $H$. annuus and $H$. tuberosus pollen was not very high, being 15 and $16 \%$ respectively (Table 1). Most of the globular embryos obtained after these crosses were well formed, although they did not develop further and, at 9-10 DAP, they started to degenerate. Several days after crossing with $H$. annuи and $H$. tuberosus, a cellular endosperm was formed in some embryo sacs. The structure of this endosperm with large nuclei and numerous micronucleoli (Fig. 2f) conspicuously differed from the endosperm of control diploid plants.

\section{Regenerated plants after embryo rescue}

As globular embryos obtained after crossing with either Helianthus species collapsed during the early stages of embryogenesis, it was necessary to transfer them onto various MS media (Table 2). During the culture of embryo sacs surrounded by endothelium (Fig. 3a), proembryos (inside the embryo sacs) did not develop further, although after a few days, some of them proliferated extensively leading to the formation of callus tissue (Fig. 3b, c). Callus induction was achieved on two modified MS media: MS + 2,4-D $1 \mathrm{mg} \mathrm{l}^{-1}+\mathrm{NAA} 1 \mathrm{mg} \mathrm{l}^{-1}$, and MS + BAP $2 \mathrm{mg} \mathrm{l}^{-1}+$ IAA $1 \mathrm{mg}^{-1}$ (Tables 2, 3). Morphogenic calluses grew very rapidly and completely covered the remnants of the embryo sacs (Fig. 3d). These calluses were compact and of hard consistency. The histological analysis of the callus tissue (not shown), revealed their high regeneration potential, manifested by the presence of many meristematic centres and numerous vascular bundles. The morphogenic calluses transferred to jars containing MS medium with added kinetin started to turn green after a few days of culturing. During the next few days, the roots and first primordia of leaves were regenerated. After approximately 4 weeks of culture a large number of well-developed shoots with leaf rosettes appeared on the surface of the growing calluses (Fig. 3e). When the roots were well developed, plantlets of $L$. sativa were moved to water with mineral salts and, after 7 days were transferred to soil (Fig. 3f). From 29 cultured calluses, 23 plants were regenerated (Table 3). The obtained plants were tested using multiple methods to verify their ploidy level.

Ploidy level of the obtained plants

The ploidy level of 23 regenerated plants was estimated by counting chromosomes in the dividing meristematic cells of roots, analysis of late stages of microsporogenesis, and measurements of leaf stoma cells and genome size by flow cytometry. The relative DNA content (2C) in haploid plants was $2.87 \pm 0.01 \mathrm{pg}$ and that in the control plants $5.74 \pm 0.02 \mathrm{pg}$, which clearly confirmed the haploidy of the regenerated plantlets (Fig. 4a, b). A haploid chromosome number $(n=9$; Fig. $4 a)$ was established at the metaphase of root cells of regenerated plants and a diploid number in the control plants $(2 n=18$; Fig. 4b). The leaves of L. sativa are amphistomatic. Leaf stomatas are the anomocytic type. The average length of the stomata of the regenerated plants $(23.05 \pm 1.68 \mu \mathrm{m}$; Fig. 5a) was nearly half that of the control diploid $(39.48 \pm 3.14 \mu \mathrm{m}$; Fig. $5 \mathrm{~b})$, with this difference between haploid and diploid plants being significant ( $\mathrm{p}<0.001$; Student's $t$-test) (Fig. 6). 

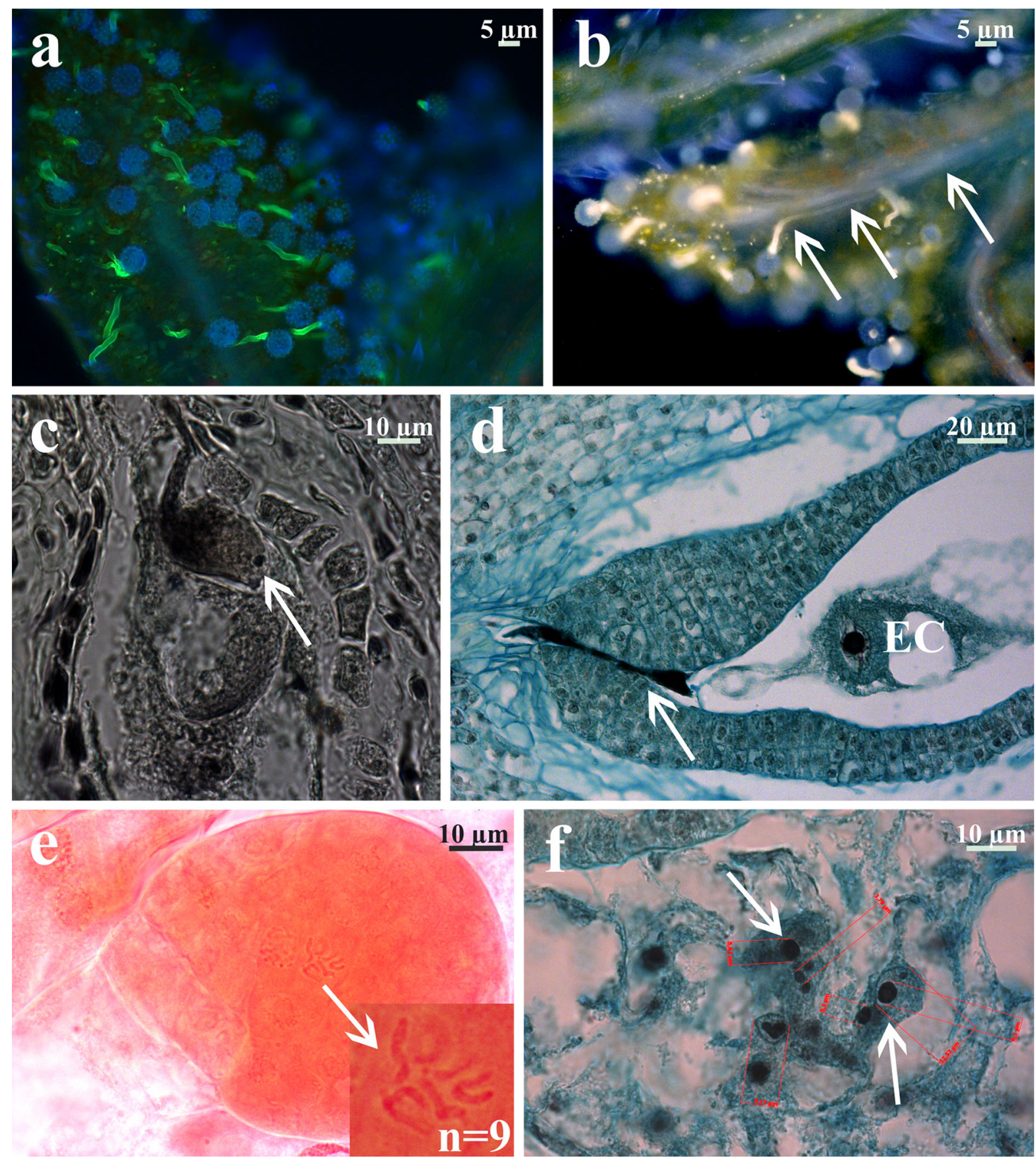

Fig. 2 Distant pollination of L. sativa with two Helianthus species: a, b pollen tubes of $H$. tuberosus penetrated the stigma at $1 \mathrm{~h}$ after pollination (HAP) (a) and the style of L. sativa at 2 HAP (b); c pollen tube with sperm cell of H. annuus (arrow) entering the embryo sac; $\mathbf{d}$ pollen tube of H. tuberosus (arrow)

In haploid regenerants of $L$. sativa, late stages of microsporogenesis were disturbed by unequal divisions of the microsporocytes and, instead of the inside the embryo sac (with visible egg cell: EC) at 2 days after pollination (DAP); e globular haploid embryo of L. sativa at 6 DAP with $H$. tuberosus, metaphase plate with $(\mathrm{n}=9)$ inserted; f nuclei of endosperm (arrows) developed at 6 DAP with $H$. annuus

development of normal microspore tetrads (Fig. 7a), the formation of diads, triads (Fig. 7b) and even pentads occurred (Fig. 7c). Some microspores were 


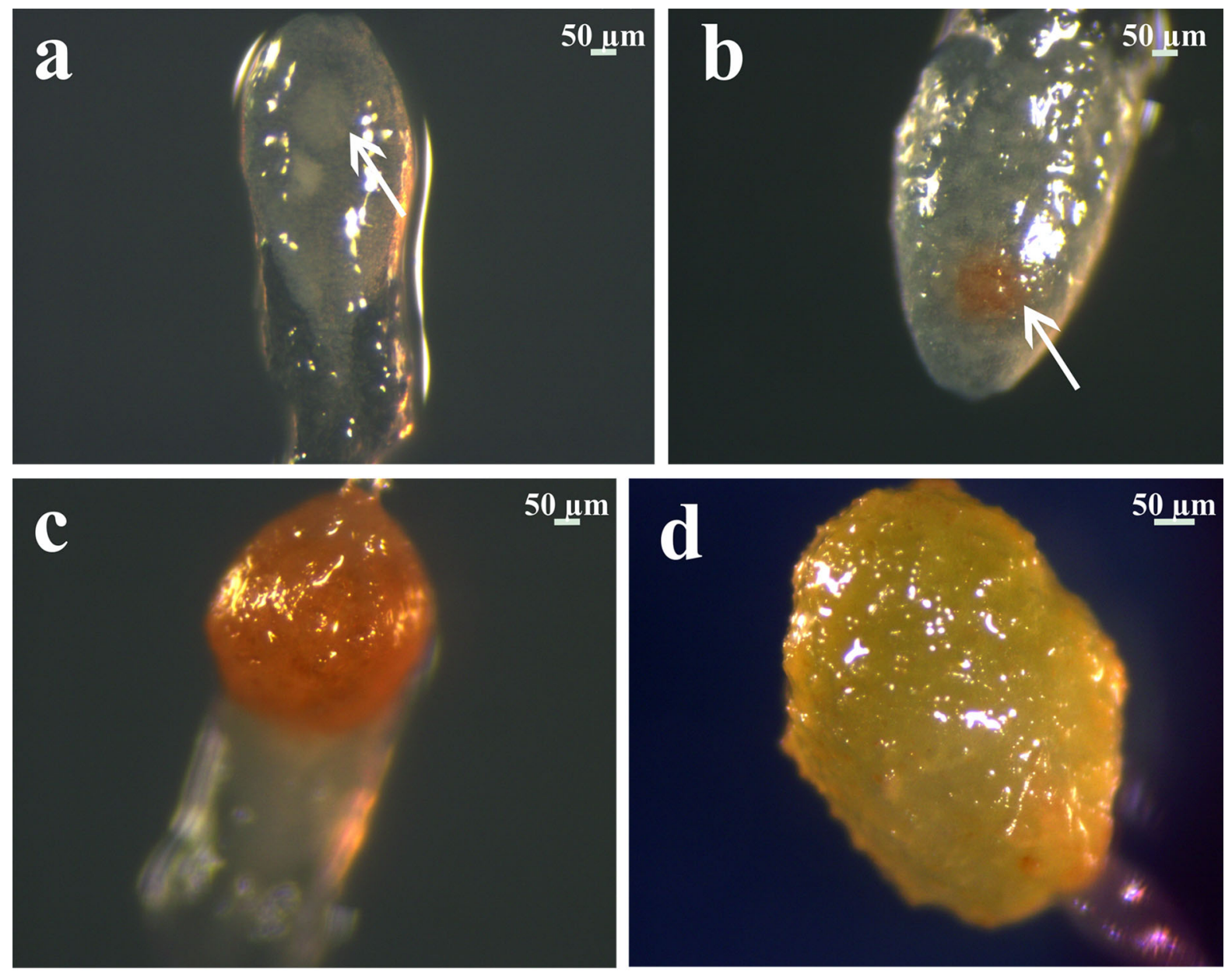

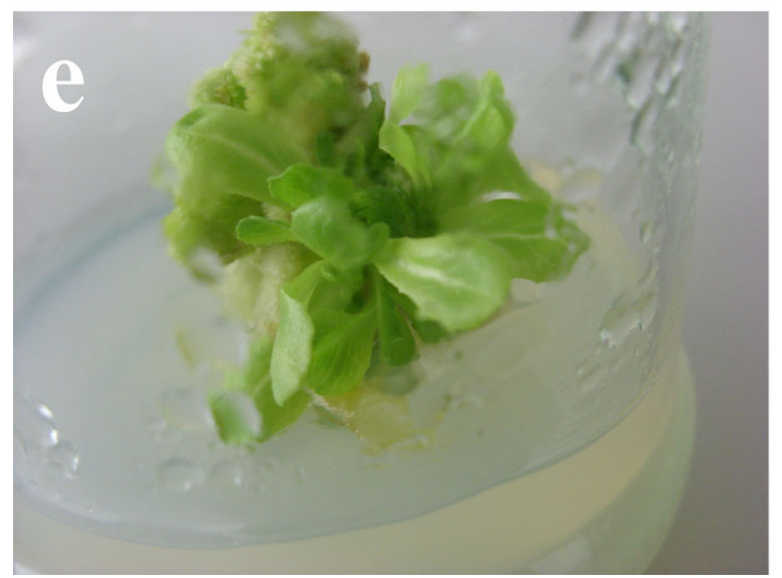

Fig. 3 Regeneration of haploid plants of L. sativa: a isolated embryo sac with haploid, globular embryo (arrow) at 6 DAP with $H$. tuberosus; b proliferating embryo at 15 days after culture on $\mathrm{MS}+2,4-\mathrm{D} 1 \mathrm{mg} \mathrm{l}^{-1}+\mathrm{NAA} 1 \mathrm{mg} \mathrm{l}^{-1} ; \mathbf{c}$,

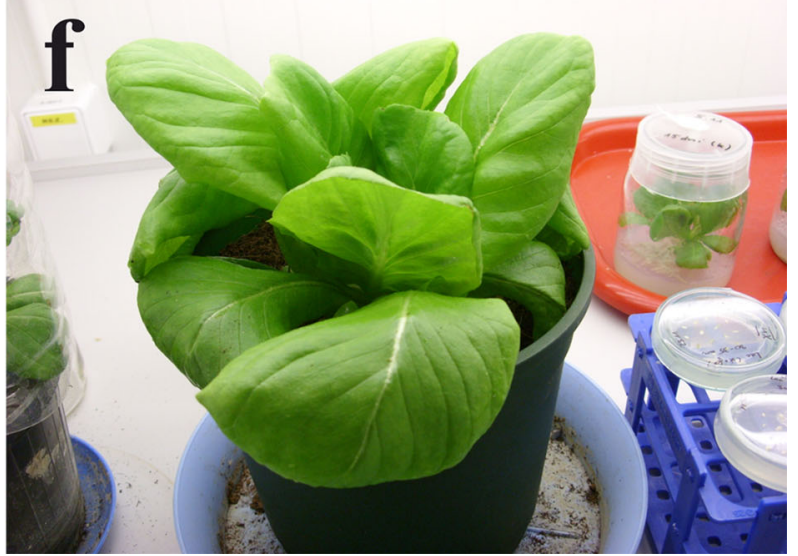

d callusing embryo after 25 days (c) and 40 days of culture (d); e haploid plantlet of $L$. sativa regenerated from callus after 65 days of culture; $\mathbf{f}$ well-developed haploid plant of lettuce 
Fig. 4 Plant habit, chromosome numbers and histograms of relative DNA content of haploid (a) and diploid L. sativa plants (b)
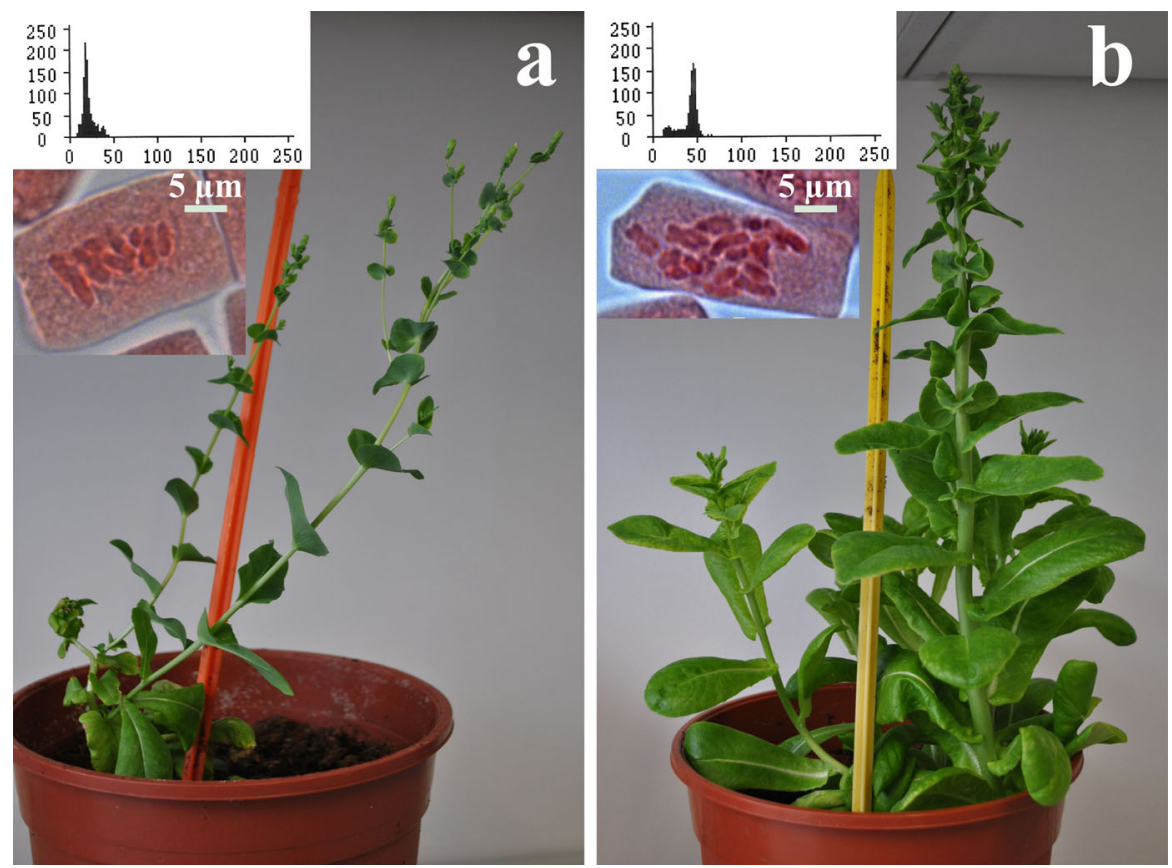
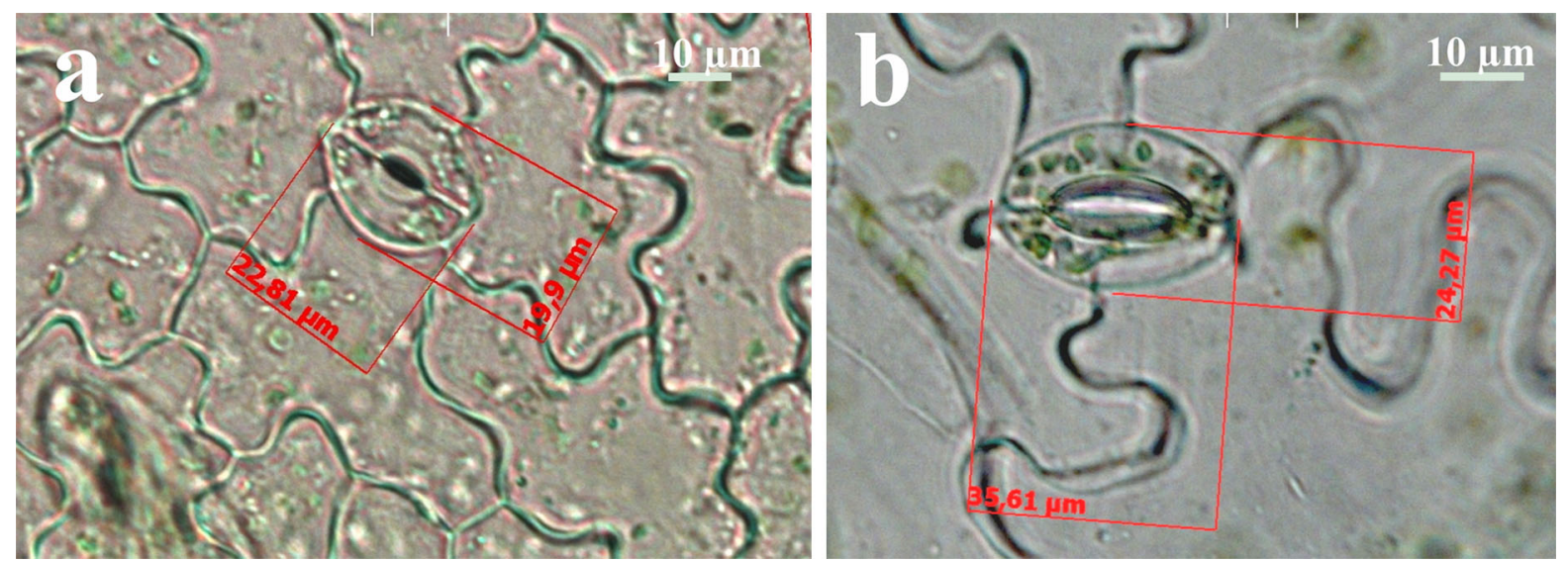

Fig. 5 Leaf stomata shapes and sizes of haploid (a) and diploid plants (b)

three to four times smaller than others. On rare occasions, 3 days before anthesis, the presence of separated and properly developed microspores of haploid plants was ascertained. These microspores were characterised by a low level of vacuolisation and centrally located nuclei (Fig. 7d). However, on the subsequent days (until flowering), microspores of the haploid material started to degenerate (strong vacuolisation of cells and degradation of the cell nuclei, cytoplasm and cell walls). On the day of flowering, the anthers of haploid plants were fully packed with completely degenerated microspores (Fig. 7e). In the anthers of the diploid control plants, normal microsporogenesis led to microspore tetrads surrounded by the common callose wall (Fig. 7f). In these plants, 3 days before anthesis, the separated microspores with central nuclei were properly formed (Fig. 7g). During flowering, well-developed pollen grains were present in the anthers of the control material (Fig. 7h). 


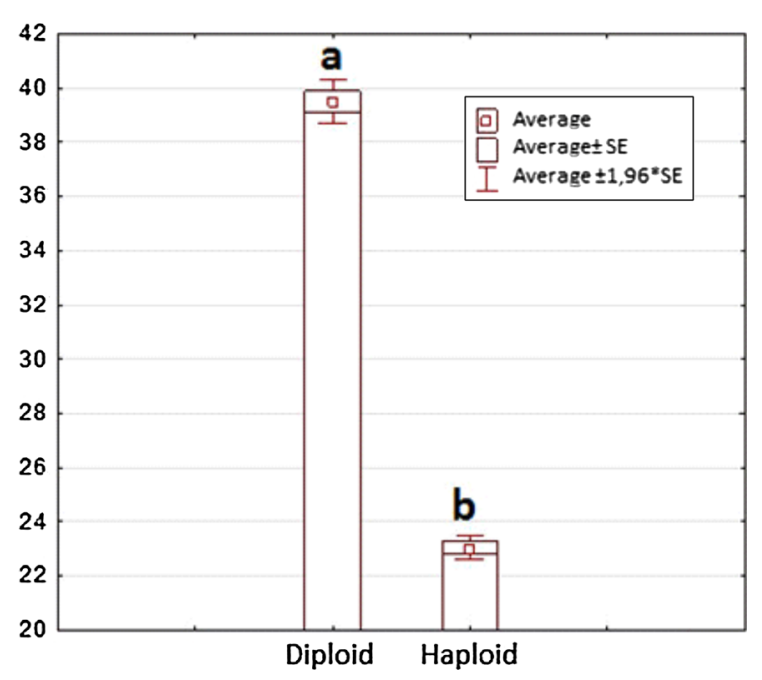

Fig. 6 Average length of stomata of haploid and diploid plants. The different letters indicate significant differences $( \pm \mathrm{SE})$ according to Student's $t$-test

\section{Discussion}

Biotechnologists and plant breeders are ceaselessly searching for effective methods for haploidisation that can be applied to a range of plant species. The efficiency of obtaining haploid plants may depend on the method used, the genotype of the plant material, or the physiological conditions, as has been shown for example in Beta vulgaris (Doctrinal et al. 1989). In vitro culture techniques reveal the different regeneration potential of individual explants, such as unfertilised ovules or isolated anthers. However, in many species (especially trees), the process of haploidisation may be difficult (Mohan Jain et al. 1996).

Among the various methods of haploidisation that have been successfully applied to other species, the distant pollination technique was chosen to induce the development of haploid embryos with the maternal genome of $L$. sativa. For stimulating the process of parthenogenesis in lettuce, pollen grains of 25 different species were used. Among these, the most effective were crosses with pollen of $H$. annuus and H. tuberosus - these species were used for the subsequent experiments (Piosik 2013).

Induction of the development of haploid embryos by distant pollination proved to be relatively easy. Pollen grains of both Helianthus species germinated on stigmas of lettuce within a few hours of pollination. Long and well-developed pollen tubes with two male gametes of $H$. annuus or $H$. tuberosus penetrated the styles and entered the embryo sac. On the following days, haploid $(n=9)$ embryos developed. Published reports suggest that the presence of foreign pollen grains on stigmas may be an important factor for stimulating the growth of haploid embryos, such as in Cichorium intybus (Dore et al. 1996). During our experiments, neither fertilisation of the egg cell of lettuce nor the presence of hybrid embryos was observed in either of the two combinations of pollination with Helianthus species. The development of hybrid embryos and plants of lettuce was previously reported only after crossing with genetically related species such as $L$. saligna, L. virosa and $L$. serriola (D'Andrea et al. 2008; de Vries 1990). After pollination with $H$. annuus or $H$. tuberosus cellular endosperm showing signs of hybridity (number of chromosomes, large nuclei and multinucleoli) developed. This could indicate that fertilisation of the central cell can occur (Piosik 2013).

The presence of incompatible endosperm and the process of early inhibition of embryo development are often the main reasons of degeneration of embryos in vivo. The embryo-rescue method has proven to be helpful in such cases. This method can be applied on media inducing the development of haploid or hybrid globular proembryos. For this purpose, whole ovaries, ovules or even embryos can be isolated and cultured in vitro (Sharma et al. 1996). The embryo-rescue method was used for the first time in the cultures of isolated embryos of Phaseolus and Fagopyrum, which developed to mature plants (Schopfer 1943). This method is especially useful when the endosperm does not form or when it develops poorly, for example, after crossing Salix and Populus (Zenkteler et al. 2005). The embryo-rescue technique was also successfully implemented for obtaining hybrids after a combination of crossings, such as wheat $\times$ rye (Oettler 1984), wheat $\times$ maize (Laurie 1990) and willow $\times$ poplar (Bagniewska-Zadworna et al. 2011). Owing to the lack of compatible endosperm and the early degeneration of parthenogenetic embryos of L. sativa, the method of embryo rescue was successfully used in this work. However, because of the small size of the haploid proembryos of lettuce, their isolation for embryo rescue was not possible, but whole embryo sacs (surrounded by endothelium) with proembryos inside them could be isolated relatively easily. It is well known that the regeneration of plants from 

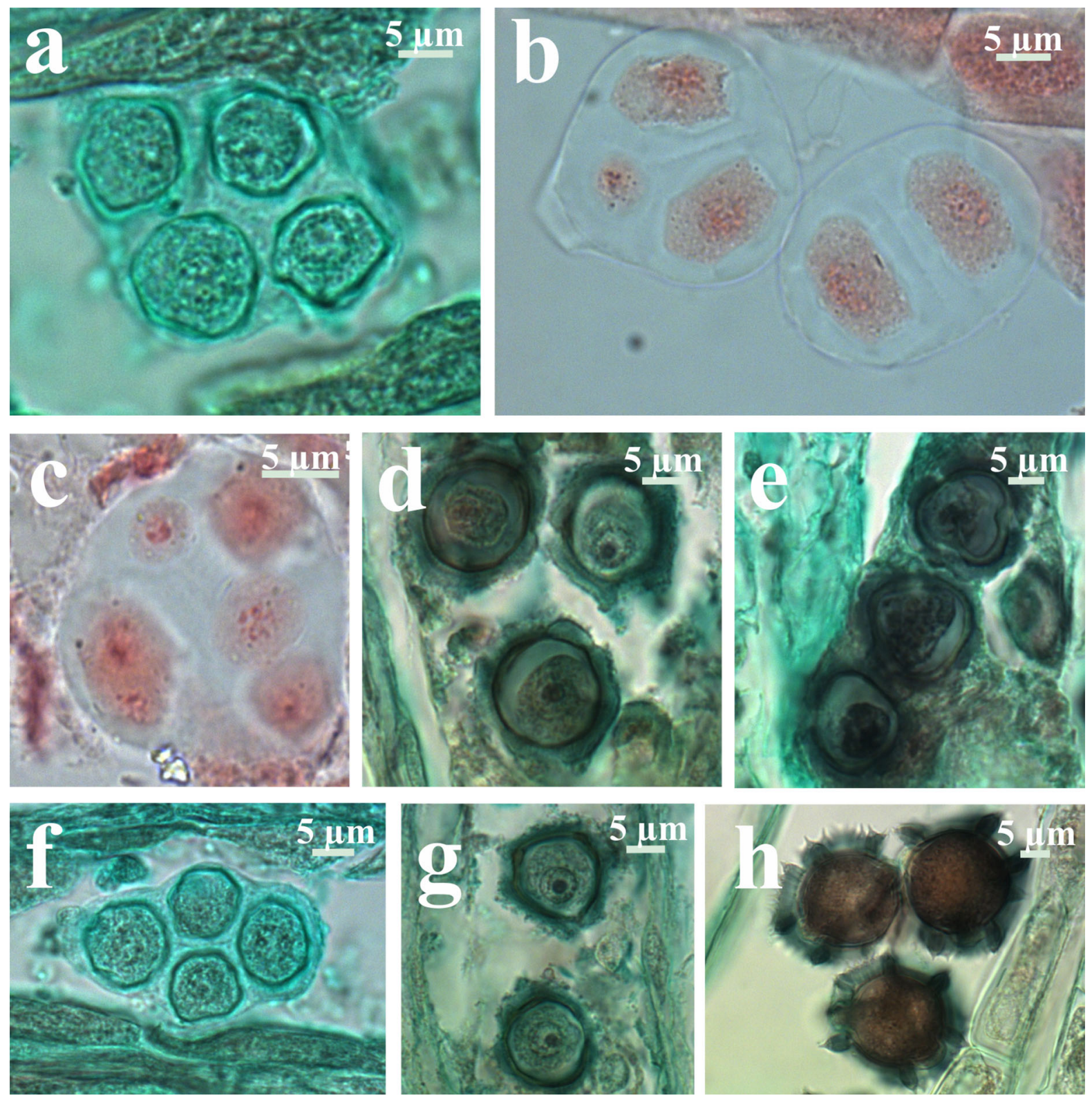

Fig. 7 Microspore tetrad stage and pollen grains of haploid (ae) and diploid (f-h) L. sativa plants: a normal tetrad stage 9 days before anthesis; b-d disturbed meiosis resulting in diad, triad (b) and pentad formation (c); d separated microspores 3 days

proembryos in vitro depends on the genotype and specific composition of the medium. In vitro cultures of globular embryos need medium enriched with high concentrations of sucrose, coconut water, casein hydrolysate or phytohormones (Sharma et al. 1996). In our investigations, 28 modified MS media were used to induce the development of haploid before anthesis; e degenerated microspores on the day of flowering; $\mathbf{f}$ tetrad of microspores 9 days before anthesis; $\mathbf{g}$ welldeveloped microspores 3 days before anthesis; $\mathbf{h}$ pollen grains on the day on which inflorescences opened

proembryos of L. sativa. No cultured proembryos developed further on any tested MS media, and only rarely did embryos located inside the embryo sacs produce calluses. These calluses originated from the dividing cells of haploid embryos. The formation of haploid calluses has frequently been described, for example, during the process of androgenesis of tomato 
(Shtereva et al. 1998) and cucumber (Song et al. 2007), or during the gynogenesis of Gerbera (Miyoshi and Asakura 1996). Calluses were characterised by high regeneration potency manifested by the presence of numerous shoots and leaf rosettes on the surface of calluses. As a result of the in vitro cultures, we regenerated 23 haploid plants of L. sativa; however, it must be stressed that this number could potentially have been increased because, in our work, we mainly focused on establishing a method enabling the production of haploid plants of lettuce.

\section{Conclusions}

Application of the method of distant pollination of $L$. sativa with $H$. annuus or $H$. tuberosus and the technique of embryo rescue makes it possible to obtain haploid plants of L. sativa. Haploids of lettuce provide a good base to produce double-haploid (DH) lines and, in the future, it is likely that new varieties of this common species will be generated.

Acknowledgments The authors thank the Rijk Zwaan Company (Fijnaart, The Netherlands) for providing L. sativa and $H$. annuus plants and for the opportunity to conduct this research.

Open Access This article is distributed under the terms of the Creative Commons Attribution 4.0 International License (http:// creativecommons.org/licenses/by/4.0/), which permits unrestricted use, distribution, and reproduction in any medium, provided you give appropriate credit to the original author(s) and the source, provide a link to the Creative Commons license, and indicate if changes were made.

\section{References}

Bagniewska-Zadworna A, Zenkteler M, Zenkteler E, Wojciechowicz MK, Barakat A, Carlson JE (2011) A successful application of the embryo rescue technique as a model for studying crosses between Salix viminalis and Populus species. Aust J Bot 59:382-392

Bradley FM, Ellis BW, Martin DL (2009) The organic gardener's handbook of natural pest and disease control. Rodale, New York

Cegielska-Taras T (2004) Doubled haploids in oilseed rape (Brassica napus L.). Oilseed Crops 19:353-357

D'Andrea L, Felber F, Guadagnuolo R (2008) Hybridization rates between lettuce (Lactuca sativa $\mathrm{L}$.) and its wild relative (L. serriola) under field conditions. Environ Biosaf Res 7:61-71
De Vries M (1990) Crossing experiments of lettuce cultivars and species (Lactuca sect. Lactuca, Compositae). Plant Syst Evol 171:233-248

De Vries M (1997) Origin and domestication of Lactuca sativa L. Genet Res Crop Evol 44:165-174

Doctrinal M, Sangwan RS, Sangwan-Norreel BS (1989) In vitro gynogenesis in Beta vulgaris L.: effects of plant growth regulators, temperature, genotypes and season. Plant Cell Tissue Organ Cult 17:1-12

Doi H, Yukoi S, Hikage T, Nishihara M, Tsutsumi K, Takahata Y (2011) Gynogenesis in gentians (Gentiana triflora, $G$. scabra): production of haploids and doubled haploids. Plant Cell Rep 30:1099-1106

Dore C, Prigent J, Desprez B (1996) In situ gynogenetic haploid plants of chicory (Cichorium intybus L.) after intergeneric hybridization with Cicerbita alpina Walbr. Plant Cell Rep 15:758-761

Dubas E, Custers J, Kieft H, Wędzony M, van Lammeren AAM (2014) Characterization of polarity development through 2- and 3-D imaging during the initial phase of micropore embryogenesis in Brassica napus L. Protoplasma 251:103-113

Galbraith DW, Harkins KR, Maddox JM, Ayres NM, Sharma DP, Firoozabady E (1983) Rapid flow cytometric analysis of the cell cycle in intact plant tissues. Science 220:1049-1051

Gośka M, Krysińska T, Strycharczuk T (2004) The use of in vitro gynogenesis for obtaining sugar beet dihaploids. Biul Inst Hod Rośl 234:27-34

Gu J, Liu K, Li S, Tian Y, Yang H, Yang M (2008) Study on the in vitro culture of cut plants in wheat haploid embryo induction by a wheat $\times$ maize cross. Front Agric China 2(4):391-395

Kasha KJ, Kao KN (1970) High frequency haploid production in barley (Hordeum vulgare L.). Nature 225(5235):874-876

Kiełkowska A, Adamus A, Barański A (2014) An improved protocol for carrot haploid and doubled haploid plant production using induced parthenogenesis and ovule excision in vitro. In Vitro Cell Dev Biol Plant 50:376-383

Kurtar ES, Balkaya A, Ozbakir M, Ofluoglu T (2009) Induction of haploid embryo and plant regeneration via irradiated pollen technique in pumpkin (Cucurbita moschata Duchesne ex. Poir). Afr J Biotechnol 8(21):5944-5951

Kyung-Moon K, Baenziger PS (2005) A simple wheat haploid and doubled haploid production system using anther culture. In vitro Cell Dev Biol Plant 41:22-27

Laurie, DA, O'Donoughue LS, Bennett MD (1990) Wheat $\times$ maize and other wide sexual hybrids: their potential for genetic manipulation and crop improvement. In: Gustafson JP (ed), Proceedings 19th Stadler Genetics Symposium Columbia, March 13-15, 1989, Plenum Press, Columbia, pp 95-126

Miyoshi K, Asakura N (1996) Callus induction, regeneration of haploid plants and chromosome doubling in ovule cultures of pot gerbera (Gerbera jamesonii). Plant Cell Rep 16:1-5

Mohan Jain S, Sopory SK, Veilleux RE (1996) In vitro haploid production in higher plants. Volume 3: important selected plants. Springer

Mól R (1999) Embryological aspects of in vitro gynogenesis in plant organ cultures. Acta Biol Crac Ser Bot 41:67-74

Murashige T, Skoog F (1962) A revised medium for rapid growth and bioassays tobacco tissue culture. Physiol Plant 15:473-497 
Musiał K, Przywara L (1998) Influence of irradiated pollen on embryo and endosperm development in kiwifruit. Ann Bot 82:747-756

Musiał K, Przywara L (1999) Response of endosperm to pollen irradiation in kiwifruit. Sex Plant Reprod 12:110-117

Musiał K, Bohanec B, Przywara L (2001) Embryological study on gynogenesis in onion (Allium cepa L.). Sex Plant Reprod 13:335-341

Musiał K, Bohanec B, Jakse M, Przywara L (2005) The development of onion (Alium cepa $\mathrm{L}$.) embryo sacs in vitro and gynogenesis induction in relations to flower size. In Vitro Cell Dev Biol Plant 41:446-452

Nasertorabi M, Madadkhah E, Moghbeli E, Grough MSH, Soleimani A (2012) Production of haploid lines from parthenogenetic Iranian melon plants obtained of irradiated pollen (Cucumis melo L.). Int Res J Appl Basic Sci 3(8):1585-1589

Oettler G (1984) Parental effects of crossability, embryo differentiation and plantlet recovery in wheat $\times$ rye hybrids. Euphytica 33:233-239

Pandey KK, Przywara L, Sanders PM (1990) Induced parthenogenesis in kiwifruit (Actinidia deliciosa) through the use of lethally irradiated pollen. Euphytica 51:1-9

Piosik $Ł$ (2013) Haploid embryos of lettuce (Lactuca sativa) induced by alien pollen or chemical factors. Afr $\mathrm{J}$ Biotechnol 12(4):345-352
Radojevic I, Marinkovic N, Jevremovic S (2000) Influence of the sex of flowers of androgenesis in Aesculus hippocastanum L. anther culture. In Vitro Cell Dev Biol Plant 36:464-469

Schopfer WH (1943) Plants and vitamins. Chronica Botanica Co., Waltham

Segui-Smiarro JM, Corral-Martinez P, Parra-Vega V, GonzalesGarcia B (2011) Androgenesis in recalcitrant solanaceous crops. Plant Cell Rep 30(5):765-768

Sharma DR, Kaur R, Kumar K (1996) Embryo rescue in plants-a review. Euphytica 89:325-337

Shtereva LA, Zagórska NA, Dimitrov BD, Kruleva MM, Oanh HK (1998) Induced androgenesis in tomato (Lycopersicon esculentum Mill). II. Factors affecting induction of androgenesis. Plant Cell Rep 18:312-317

Song H, Lou Q, Luo X, Wolukau JN, Diao W, Qian C, Chen J (2007) Regeneration of doubled haploid plants by androgenesis of cucumber (Cucumis sativus L.). Plant Cell Tissue Organ Cult 90:245-254

Zenkteler M, Wojciechowicz M, Bagniewska-Zadworna A, Zenkteler E, Jeżowski S (2005) Intergeneric crossability studies on obtaining hybrids between Salix viminalis and four Populus species. Trees 19(6):638-643 